\title{
The dying process: its manifestation in nursing records
}

\author{
O processo de morrer: que expressão tem nos registos de enfermagem \\ El proceso de muerte: qué expresión tiene en los registros de enfermería \\ Maria Filomena Passos Teixeira Cardoso*iD; Maria do Carmo Cardoso Morais Lessa Silva**iD; \\ Cecília Maria Pereira de Macedo Alves*** (iD); Maria Manuela Ferreira Pereira da Silva Martins**** (DD)
}

\begin{abstract}
Background: Despite the changes over the last decade in nursing care, some concerns about the care practice in the process of dying remain.

Objective: To analyze the focus documented by nurses during the dying process within the hospital context and to identify the differences in records relating to the focus valued in the different clinical areas.

Methodology: As part of a larger research project called Living Death: the challenge of the nursing profession, this quantitative, descriptive, and retrospective documentary study was performed based on the analysis of 36,281 nursing actions documented by 1,270 nurses.

Results: Of the 36,281 actions recorded, most of the documentation is related to Function (56.5\%), followed by Person (43.5\%), which shows an apparent disregard for the transitions experienced by patients within the context of death and the processes of dying.

Conclusion: It is increasingly important to decentralize the attention of a practice that is predominantly focused on the biomedical component, in favor of care focusing on the experiences facing the imminence and inevitability of death.
\end{abstract}

Keywords: electronic health records; nursing; death

\section{Resumo}

Enquadramento: Apesar da mudança significativa na documentaçáo dos cuidados de enfermagem ocorrida na última década, no âmbito do processo de morrer existem ainda algumas fragilidades que demonstram necessidade de serem estudadas.

Objetivo: Analisar os focos de enfermagem documentados pelos enfermeiros, durante o processo de morrer no contexto hospitalar e identificar as diferenças de registos relativos aos focos valorizados nas diferentes áreas clínicas. Metodologia: Integrado numa investigação mais ampla intitulada Viver a Morte: desafio da profissão de enfermagem, este estudo quantitativo, descritivo e retrospetivo documental, foi realizado recorrendo à análise de 36.281 focos de enfermagem documentados por 1.270 enfermeiros. Resultados: Dos 36.281 focos registados, verifica-se que a maioria da documentação é relativa à Função (56,5\%), seguindo-se a Pessoa $(43,5 \%)$, dados que evidenciam uma aparente desvalorização das transiçóes vivenciadas pelas pessoas, no âmbito da morte e dos processos de morrer.

Conclusáo: Torna-se emergente descentrar a atenção de uma prática predominantemente focada na componente biomédica, em prol de um cuidado centrado nas experiências vivenciadas pelas pessoas diante da iminência e inevitabilidade da finitude da vida.

Palavras-chave: registos eletrónicos de saúde; enfermagem; morte

*MSc., Ph.D. student in Nursing Science, ICBAS. Lecturer, Fernando Pessoa University. Head Nurse, São João Hospital Center, 4200-319, Porto, Portugal [ptcardoso@gmail.com]. (D) https://orcid.org/0000-0001-5758-2310. Contribution to the article: bibliographical research, data collection and analysis, and writing of the article. Address for correspondence: Alameda Professor Hernâni Monteiro, 4200-319, Porto, Portugal.

**BSc., Nurse Specialist, São João Hospital Center, 4200-319, Porto, Portugal [ptcardoso@ gmail.com]. (1) https://orcid.org/0000-0002-6049-3068. Contribution to the article: data analysis and discussion.

**MSc., Nurse Specialist, São João Hospital Center, 4200-319, Porto, Portugal [ptcardoso@ gmail.com]. (1) https://orcid.org/0000-0003-2228-7623. Contribution to the paper: data analysis and discussion.

****:Ph.D., Coordinating Professor, Higher School of Nursing of Porto. Researcher, Research Centre for Health Technologies and Services, NursID Research Group: Innovation and Development in Nursing, 4200-450, Porto, Portugal [mmmartins1956@gmail.com]. (D) https:/4 orcid.org/0000-0003-1527-9940. Contribution to the paper: data analysis and discussion and writing of the article.

\section{Resumen}

Marco contextual: A pesar del cambio significativo en la documentación de los cuidados de enfermería, ocurrido en la última década, en el marco del proceso de morir, existen todavía algunos puntos críticos que siguen precisando un estudio más a fondo.

Objetivo: Analizar los puntos de enfermería documentados por los enfermeros, durante el proceso de morir en el contexto hospitalario e identificar las diferencias en los registros relacionados con los focos valorados en las diferentes áreas clínicas.

Metodología: Integrado en una investigación más amplia titulada Vivir la Muerte: desafío de la profesión de enfermería, este estudio cuantitativo, descriptivo y retrospectivo documental, fue realizado recurriendo al análisis de 36.281 focos de enfermería documentados por 1.270 enfermeros. Resultados: De los 36.281 focos registrados, se verifica que la mayoría de la documentación se refiere a la Función $(56,5 \%)$, seguida de Persona $(43,5 \%)$, datos que evidencian una aparente devaluación de las transiciones vivenciadas por las personas, en el ámbito de la muerte y de los procesos de morir.

Conclusión: Es prioritario descentrar la atención de una práctica predominantemente enfocada en la componente biomédica, en pro de un cuidado centrado en las experiencias vivenciadas por las personas ante la inminencia e inevitabilidad de la finitud de la vida.

Palabras clave: registros electrónicos de salud; enfermería; muerte

Received for publication: 23.03.19

Accepted for publication: 06.06.19

Série IV - n. ${ }^{\circ} 21$ - ABR./MAI./JUN. 2019 


\section{Introduction}

Death has always aroused great concern and curiosity in the human being. Despite everything, death is always present in us, constituting one of the greatest mysteries and one of the hardest realities that we must face when we see the bonds we built disappear with the departure of a loved one. While this is a physiological process that occurs with the absence of all vital signs, it is also a cultural process that entails denial of loss and the difficulty in accepting it, involving ethical, cultural, religious and socio-environmental dimensions (Lacerda et al., 2016).

Death is the ultimate act of life on earth, just as birth marks its beginning. The only certainty about our life is that one day we die, although we do not know why, when, where, and how. "Death is one of the only certainties of life, and it should be natural in terms of its acceptance, as it occurs in all living beings and, logically, is an integral part of the human life cycle" (Oliveira, Quintana, \& Bertolino, 2010, p. 1080).

Every human being carries with him a personal representation of death. The development of such representation is influenced by social life, media, and the particularities of each person. As Sousa, Soares, Costa, Pacífico, and Parente (2009, p. 42) underscore:

It is in this scenario of diversity with regard to death that nursing professionals find themselves living in constant challenge, faced with the daily battle of life against death, taking on the responsibility of saving, healing or alleviating, always striving to preserve life, as these professionals regard death, for the most part, like failure, which must be fought against.

Nurses, who are essentially trained to prevent disease and promote health, should be taught not to regard death as a defeat or source of demotivation. They should look at it as a phase during which their work is instrumental for helping patients and their families endure the process in comfort. As some authors claim,

The nurse is the person closest to the patient in hard times and is the one the patient and the family turn to for explanation or immediate care. Such care requires not only knowledge of pathology but also knowing how to deal with the feelings of others, and one's own emotions in the face of an illness that may or may not be cured.

(Lima et al., 2014, p. 504)

The problem is that "the mostly technical training that the school offers the undergraduate, instead of addressing issues concerning emotions, especially those caused by death, contributes to the lack of preparation in coping with death in professional activities" (Lima et al., 2014, p. 506). Moreover, do nurses' records reflect their intervention in the process of dying?

Following this concern and analyzing the electronic records, this study envisaged looking into the focus of the records kept by nurses in the process of care provided to dying patients and identifying the differences in records concerning the focus valued in the different clinical areas.

\section{Background}

In the last decades, there has been a change in how nursing records are kept. We went from a paper-based record to the widespread use of structured information systems. The Hospital Center under study was a pioneer in the development of the Nursing Support System (SAPE) for the Cardiology department in 1999.

SAPE was based on the model of the nursing information system developed by Silva (2001), who called it type II. The characteristics of this model are the following:

The inclusion of ICNP in the language used; the layout of the settings of contents per care unit; the construction of documentation standards; the links between natural language and classified language, both in the prior combination of terms and in the day-to-day documentation; and the vertical arrangement of data categories in the "Care Plan". In addition to these, there are also three specific characteristics of the information system model in nursing: the rules of nursing diagnosis/intervention association; the organization of nursing interventions to be implemented; and rules of referential integrity between diagnoses, status, interventions, and ongoing patient observation data. (Silva, 2001, p. 270)

Since 2010, the Hospital Center has extended the scope of nursing documentation to all inpatient care, including intensive care units, using the 
B-ICU Care information system with a type II information system model (Silva, 2001). Given that the $\beta 2$ version of the International Classification for Nursing Practice (ICNP) was in use at the time of data collection, the results of this study are presented based on this classified language.

As the same author mentioned in 2006, the usefulness of the data for management/research, for the production of indicators, and for the promotion of transformation of information into knowledge changes due to the implementation of a data structure like the one used in the information system in type II nursing, with the use of ICNP and with the change in the nursing IT support system (Silva, 2006).

In the light of these assumptions and within the scope of the larger study - Living Death: the challenge of the nursing profession, in order to study the records kept by nurses in the context of the dying process, the documents produced by nurses were analyzed retrospectively for patients who died in 2016.

\section{Research question}

Do the diagnoses recorded by nurses during the care process of deceased patients reflect their practice during the dying process?

\section{Methodology}

The developed study is a descriptive, exploratory, and retrospective documentary. Data were collected from the SClínico and B-ICU Care information systems for people who died in 2016 at a hospital in the northern region of Portugal. The nursing records of patients who died in 2016 in the surgical, medical, and intensive care areas, with clear identification of nurses, were taken from the SClínico and B-ICU Care information systems. The study identified 36,281 focuses of attention, as documented by 1,270 nurses, accounting for $98.4 \%$ of the total number of nurses in the abovementioned study areas.

The sampling technique used was non-probabilistic and intentional. The following were the exclusion criteria: records of patients under the age of 18 years and records in which the nurse was not identified.

After receiving a favorable opinion from the Ethics Committee (Opinion 102/2017), the project was approved at a meeting of the Board of Directors on March 30, 2017.

The data was collected in February 2017, by extracting from the information systems in use the registered diagnoses and creating an Excel database for further statistical analysis. In order to ensure anonymity after the focus is identified, the information on the patient and the recording nurse were eliminated.

\section{Results}

The 36,281 entries were made by 1,270 nurses who kept records in 2016 of patients who died that year.

Concerning the distribution of these nurses by area (Figure 1), most of them work in intensive care (507 nurses; $39.9 \%$ ), followed by the medical area (444 nurses; $35.0 \%$ ) and the surgical area (319 nurses; $25.1 \%$ ).

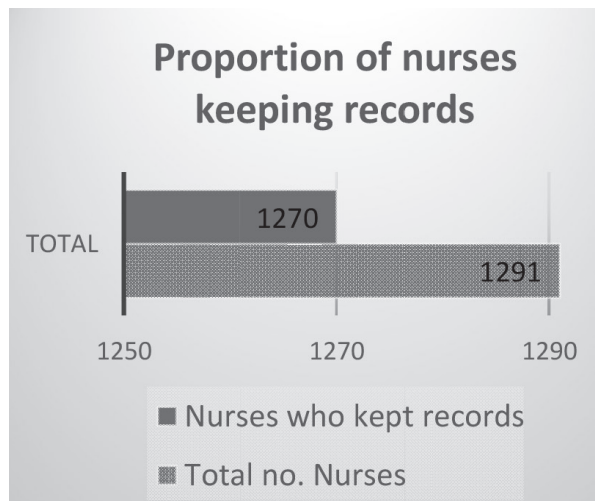

\section{Distribution of nurses keeping records by area}

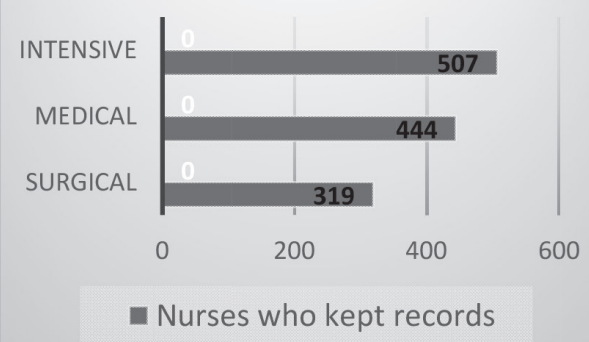

Figure 1. Distribution of nurses keeping records. 
The distribution of nurses by age is asymmetric, which means that the younger and intermediate ages are the most common, in particular nurses between the age of 30 and 40 years, while the number of nurses over the age of 35 years decreases gradually as the age goes up. The minimum age is 23 years, and the maximum age is 63 years; there is a very small number of nurses under the age of 25 years or over 60 years. Thus, the mean age is 37.4 years, slightly above the median (35 years), (that is, half of the nurses are up to 35 years old). The first quartile is 33 years (that is, a quarter of the nurses are up to 33 years old) and the 3 rd quartile is 41 years (that is, three-quarters of the nurses are up to 41 years old), which shows the prevalence of young and medium-aged nurses (Figure 2).

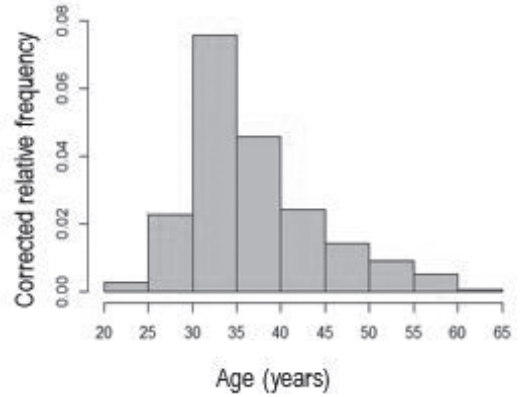

Figure 2. Graphic representation of nurse age.

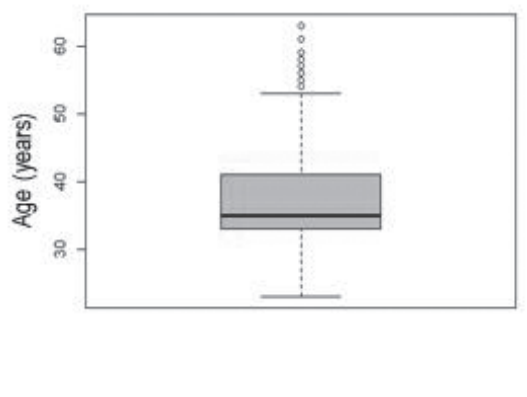

Regarding gender, there is a strong predominance of female nurses (1,002 nurses, $78.8 \%$ ). This pattern is common to all areas, with almost equal proportions in all three: 254 (79.6\%), $351(79.1 \%)$, and 397 (78.3\%) female nurses in the surgical, medical and intensive care areas, respectively.

The analysis of records kept by nurses on deceased patients was based on the organizational structure of the $\beta 2$ version of the ICNP. The incidence of foci by area of the ICNP will be described, and these were grouped into five large categories of analysis: Individual; Function; Person; Action; and Rationale for Action.

In the context of the 36,281 diagnoses recorded under the category Individual, according to Axis A -Focus of Nursing Practice, in the $\beta 2$ version of the ICNP (International Council of Nurses, 2001), it is verified that the majority of documents concern
Function (20,505 entries; 56.5\%), followed by Person (15,776 entries; 43.5\%; Figure 3).

In the surgical area there are 5,040 entries in total, with more than half of the records relating to Function (2,662 entries, 52.8\%), and less than half of the entries under Person (2,378 entries, 47.2\%). In the medical area, there are 18,941 entries in total, confirming that more than half of the entries are related to Person (9,924 entries, 52.4\%) and less than half to Function (9,017 entries, 47.6\%). In the intensive area, there are a total of 12,300 entries, most of which concern Function $(8,826$ entries, $71.8 \%)$, followed by Person $(3,474$ entries, $28.2 \%$ ).

It is verified that the intensive care area has the highest proportion of entries under Function, followed by the surgical and medical areas. Naturally, the reverse happens with the entries under the Person. 


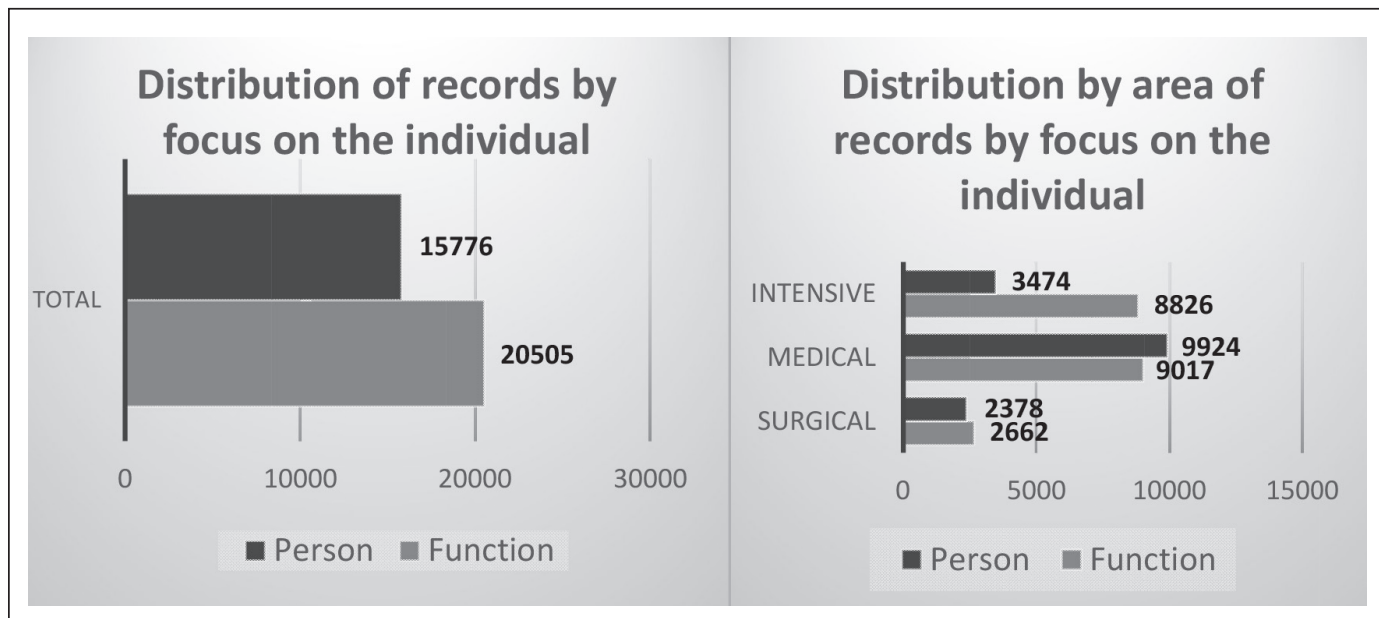

Figure 3. Distribution of records by focus on the Individual

With regard to Function, of the 16 possible diagnoses (Table 1), Tegument accounts for the majority (12,444 entries; $60.7 \%)$, followed by Breathing (2,276 entries; $11.1 \%)$, Sensations (1,407 entries; 6.9\%), Motor function (1,266 entries; 6.2\%), Elimination (881 entries; $4.3 \%$ ), Circulation (727 entries; 3.5\%), Fluid volume (647 entries; 3.2\%), Digestion (492 entries; $2.4 \%$ ), Body temperature (267 entries; $1.3 \%)$, Immune system (53 entries; $0.3 \%$ ), Repair (27 entries; 0.1\%), Nutrition (10 entries; $0.05 \%$ ), Physical development (4 entries; $0.02 \%$ ), Metabolism (3 entries; 0.01\%), and Secretion (1 entry; $0.005 \%$ ).

Table 1

Distribution of records by Function

\begin{tabular}{lcccccccc}
\hline \multirow{2}{*}{ Function } & \multicolumn{2}{c}{ Surgical } & \multicolumn{2}{c}{ Medical } & \multicolumn{2}{c}{ Intensive } & \multicolumn{2}{c}{ Total } \\
\cline { 2 - 8 } & $n$ & $\%$ & $n$ & $\%$ & $n$ & $\%$ & $n$ & $\%$ \\
\hline Motor Function & 105 & 3.9 & 440 & 4.9 & 721 & 8.2 & 1266 & 6.2 \\
Circulation & 80 & 3.0 & 188 & 2.1 & 459 & 5.2 & 727 & 3.5 \\
Physical Development & 0 & 0.0 & 2 & 0.0 & 2 & 0.0 & 4 & 0.0 \\
Digestion & 78 & 2.9 & 165 & 1.8 & 249 & 2.8 & 492 & 2.4 \\
Elimination & 43 & 1.6 & 126 & 1.4 & 712 & 8.1 & 881 & 4.3 \\
Metabolism & 1 & 0.0 & 1 & 0.0 & 1 & 0.0 & 3 & 0.0 \\
Nutrition & 0 & 0.0 & 10 & 0.1 & 0 & 0.0 & 10 & 0.0 \\
Repair & 1 & 0.0 & 25 & 0.3 & 1 & 0.0 & 27 & 0.1 \\
Breathing & 212 & 8.0 & 1013 & 11.2 & 1051 & 11.9 & 2276 & 11.1 \\
Secretion & 1 & 0.0 & 0 & 0.0 & 0 & 0.0 & 1 & 0.0 \\
Sensations & 294 & 11.0 & 321 & 3.6 & 792 & 9.0 & 1407 & 6.9 \\
Immune System & 4 & 0.2 & 39 & 0.4 & 10 & 0.1 & 53 & 0.3 \\
Tegument & 1628 & 61.2 & 6225 & 69.0 & 4591 & 52.0 & 12444 & 60.7 \\
Body Temperature & 73 & 2.7 & 132 & 1.5 & 62 & 0.7 & 267 & 1.3 \\
Volume of Fluids & 142 & 5.3 & 330 & 3.7 & 175 & 2.0 & 647 & 3.2 \\
Total & 2662 & 100.0 & 9017 & 100.0 & 8826 & 100.0 & 20505 & 100.0 \\
\hline
\end{tabular}


Concerning the focus on the Person, there are two different types of records: the majority is Action (15,199 entries; 96.3\%), the Rationale for Action being infrequent (577 entries, 3.7\%, Figure 4).
The medical area accounts for the largest share of records under Action (and the smallest share of Rational for Action), and there is no significant difference between the other two areas.

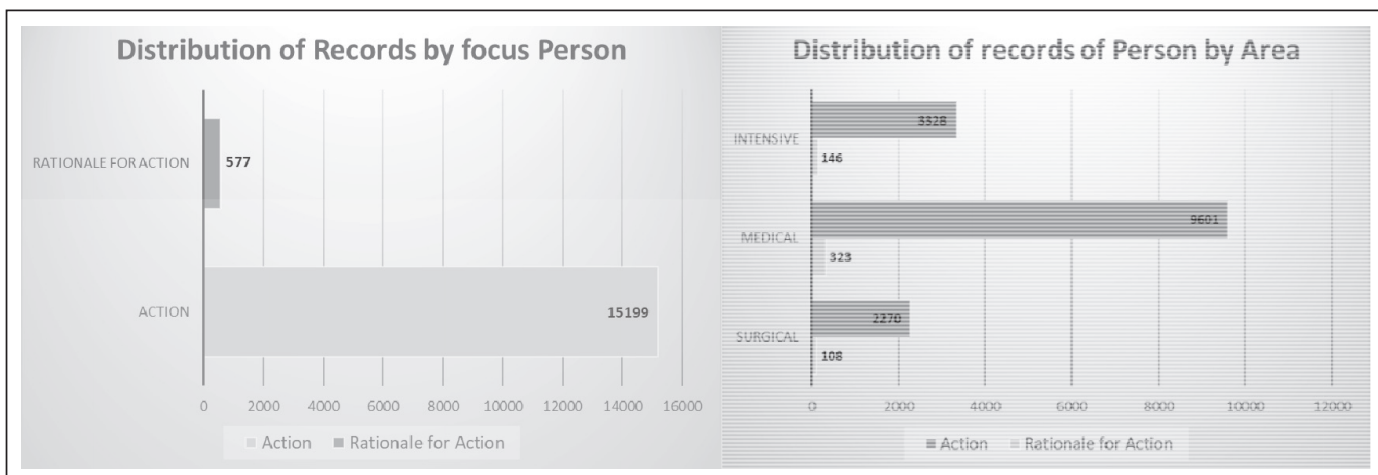

Figure 4. Distribution of records by focus on the Person

Regarding Action, in particular, it is observed that there are two different types of records: the majority concerns Actions carried out by the patient himself (15,042 entries; 99\%), whereas the interdependent Action being almost non-existent (157 entries; 1\%, Figure 5).
The medical area accounts for the largest share of entries of "Interdependent Action" (and the smallest share of entries of Actions carried out by patient himself), and there is no significant difference between the other two areas.

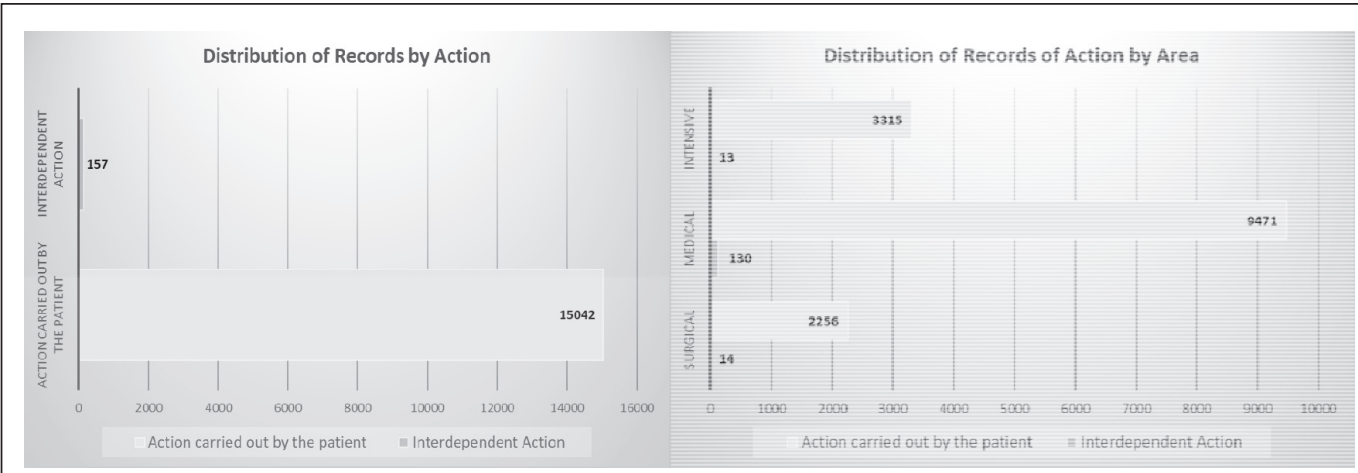

Figure 5. Distribution of records by focus on the Action

Under Action carried out by the patient himself, Self-care accounts for almost all records $(15,036$ entries, $99.96 \%$ ), and there are few concerning Lifestyles (only 6 entries, 0.04 , Table 2).

Self-care shows that the distribution of records is almost the same in all three areas, with no records of Lifestyles in the surgical and the intensive care, and only a very small number of records in the medical area. As it is not possible to test the homogeneity of proportions, it is concluded that Self-care is dominant in all areas. 
Table 2

Distribution of Records by Focus on Action carried out by the patient himself

\begin{tabular}{lcccccccc}
\hline \multirow{2}{*}{$\begin{array}{l}\text { Action carried out by } \\
\text { the patient }\end{array}$} & \multicolumn{2}{c}{ Surgical } & \multicolumn{2}{c}{ Medical } & \multicolumn{2}{c}{ Intensive } & \multicolumn{2}{c}{ Total } \\
\cline { 2 - 9 } & $n$ & $\%$ & $n$ & $\%$ & $n$ & $\%$ & $n$ & $\%$ \\
\hline Self-care & 2,256 & 100.0 & 9,465 & 99.9 & 3,315 & 100.0 & 15,036 & 100.0 \\
Lifestyles & 0 & 0.0 & 6 & 0.1 & 0 & 0.0 & 6 & 0.0 \\
Total & 2,256 & 100.0 & 9,471 & 100.0 & 3,315 & 100.0 & 15,042 & 100.0 \\
\hline
\end{tabular}

In the distribution of Interdependent Action, there are three different types of records: the Social Interaction record is the most frequent (71 entries; $45.2 \%$ ), followed by Role Interaction (50 entries; $31.8 \%$ ) and Communication (36 entries, 22.9\%; Figure 6).

The descriptive analysis shows that the most frequent record in the surgical area is Commu- nication, whereas in the medical area, the main action is Social interaction, reversing the roles about the less frequent record. Role Interaction, on the other hand, occupies the middle position in both, albeit with different proportions. In the intensive area, almost all records identified concern Communication.

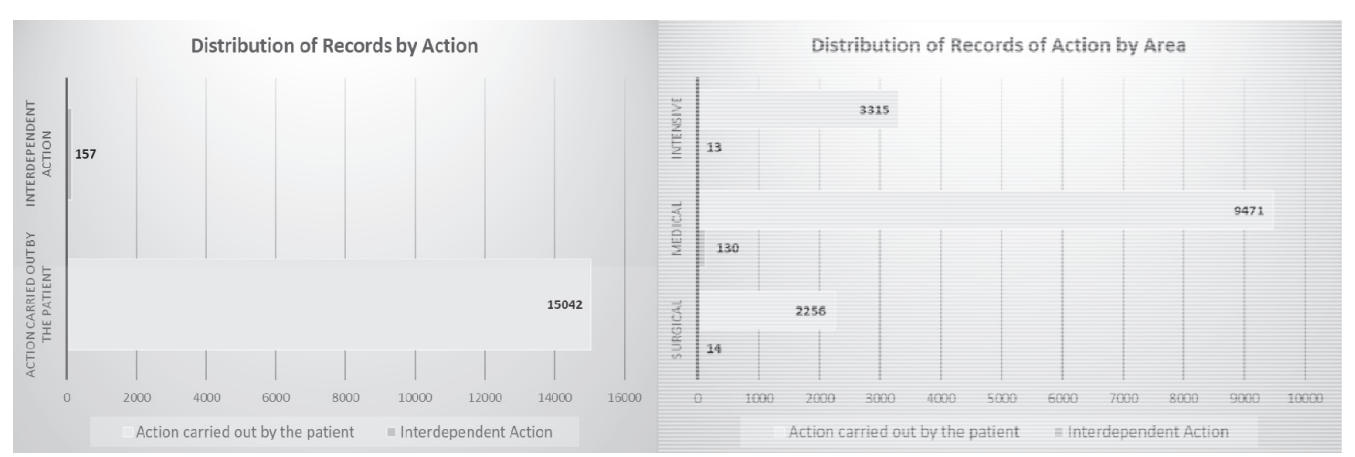

Figure 6. Distribution of records by focus on Interdependent Action

Regarding the Rationale for Action, there are two different types of records, almost all of them related to Self-knowledge (576 entries or $99.8 \%)$, Self-concept being almost non-existent (1 entry or $0.2 \%)$.
The distribution of records is the same for the Medical and Intensive areas and almost the same for Surgical. Indeed, in the first two, there are no Self-concept entries, and in the third, there is only one (Table 3 ).

Table 3

Distribution of records by focus on the Rationale for Action

\begin{tabular}{lcccccccc}
\hline \multirow{2}{*}{ Rationale for Action } & \multicolumn{2}{c}{ Surgical } & \multicolumn{2}{c}{ Medical } & \multicolumn{2}{c}{ Intensive } & \multicolumn{2}{c}{ Total } \\
\cline { 2 - 9 } & $n$ & $\%$ & $n$ & $\%$ & $n$ & $\%$ & $n$ & $\%$ \\
\hline Self-concept & 1 & 0.9 & 0 & 0.0 & 0 & 0.0 & 1 & 0.2 \\
Self-knowledge & 107 & 99.1 & 323 & 100.0 & 146 & 100.0 & 576 & 99.8 \\
Total & 108 & 100.0 & 323 & 100.0 & 146 & 100.0 & 577 & 100.0 \\
\hline
\end{tabular}


Breaking down the records, we see that, regarding Self-concept, there is only one entry that is related to Self-esteem.

The records of Self-knowledge (Table 4) are divided into six different types: Memory is the most frequent (250 entries; 43.4\%); followed by Energy (174 entries; 30.2\%); Adjustment (104 entries, 18.1\%); Cognition (23 entries; $4 \%$ ); Emotion (22 entries; 3.8\%); and Willpower (3 entries; $0.5 \%$ ).

Table 4

Distribution of records by focus on Self-knowledge

\begin{tabular}{lcccccccc}
\hline \multirow{2}{*}{ Self-knowledge } & \multicolumn{2}{c}{ Surgical } & \multicolumn{2}{c}{ Medical } & \multicolumn{2}{c}{ Intensive } & \multicolumn{2}{c}{ Total } \\
\cline { 2 - 9 } & $n$ & $\%$ & $n$ & $\%$ & $n$ & $\%$ & $n$ & $\%$ \\
\hline Adjustment & 28 & 26.2 & 68 & 21.1 & 8 & 5.5 & 104 & 18.1 \\
Cognition & 1 & 0.9 & 2 & 0.6 & 20 & 13.7 & 23 & 4.0 \\
Emotion & 1 & 0.9 & 21 & 6.5 & 0 & 0.0 & 22 & 3.8 \\
Energy & 2 & 1.9 & 119 & 36.8 & 53 & 36.3 & 174 & 30.2 \\
Willpower & 0 & 0.0 & 3 & 0.9 & 0 & 0.0 & 3 & 0.5 \\
Memory & 75 & 70.1 & 110 & 34.1 & 65 & 44.5 & 250 & 43.4 \\
Total & 107 & 100.0 & 323 & 100.0 & 146 & 100.0 & 576 & 100.0 \\
\hline
\end{tabular}

\section{Discussion}

Looking into the findings, it is clear that nurses give greater importance to the biomedical records, privileging the Function focus overall. This is particularly obvious in the area of intensive care, followed by the surgical area, whereas in the medical area the distribution in these two areas is reversed, the focus being on the Person $(52.4 \%)$. As advocated by Lindolpho, Caldas, Sá, and Santos (2016), nurses' function does not only include the performance of technical procedures, which are focused on maintaining scientific principles. Nurses are expected to recognize not only the biomedical aspects related to the dying process but also the psychosocial and spiritual implications of this experience in patients and families (Salviano et al., 2016), which the results do not demonstrate.

It is interesting to note that this emphasis on Function is most significant in the records with the focus on the Tegument in the three areas. These records highlight the concern about the prevention of pressure ulcers and the fulfillment of the recommendations of the National Plan for Patient Safety (Despacho n. ${ }^{\circ}$ 1400-A/2015, de 10 de fevereiro, 2015)).

The records on the Person are mostly (96.3\%) in the field of Action and less under Rationale for Action, which again shows the focus on the biomedical component.
According to some authors (Salviano et al., 2016), the philosophical dimension of care is part of an anthropological question that has disturbed the human being since ancient times: the meaning of the human being. The response to this concern varies according to the world view of each person, as well as their academic, social, and experiential background. Thus it is not possible to think of care as merely theorizing about action, nor can it be defined as a simple and unique structure in itself.

Detailing the records under Action, 99\% concern Actions carried out by the individual himself, of which $100 \%$ are Self-care.

After analyzing the data, and given that there are theoretical references to nursing that can support nursing practice, it is important to understand which mainly concern death and the processes of dying.

Consequently, in a broader research conducted at the national level, "Contexts of hospital practice and nursing conceptions" (Cardoso, Ribeiro, \& Martins, 2019), aimed at identifying to what extent nurses perform functions in a hospital context in line with the nursing conceptions, it was found that nurses identify themselves mostly with Virginia Henderson, and then with Dorothea Orem and Afaf Meleis. The more specific foci in the area of Self-care, potentially the high number of records, is possibly because nursing practices at the Hospital 
Center are consistent with Dorothea Orem's theoretical framework.

"Feelings such as fear, distress, and depression are expressed by individuals who are near the end of life, which, in some way, may influence and intensify their suffering" (Brito et al., 2014, p. 320). This is not visible in the data of the present study, concerning the focus on Rationale for Action, on Self-knowledge (99.8\%) in particular, showing a total disregard for emotions, which have only 22 entries.

Although there are several studies about nurses' experiences with the terminal patient (Brito et al., 2014; Lacerda et al., 2016; Lindolpho et al., 2016), this study adds a supporting analysis of the type of records kept during the dying process.

Despite the large number of records analyzed, this study is limited by the fact that it was performed in just one hospital. Furthermore, it would be interesting to complement this quantitative approach with a qualitative study that would help us understand the subjective reasons for the lack of records in the field of the Person, specifically about the Rationale for Action, which includes other focuses, such as Well-being, Emotion, and Belief.

\section{Conclusion}

Taking into account the issue under consideration, we would expect nurses to be able to recognize not only the biomedical aspects relating to the dying process but also the psychosocial and spiritual implications of this experience for the patients under their care and their families, reflecting such practice in the records.

This is not the case since a strong biomedical component is shown in the records. The significant proportion of records under Action, to the detriment of records under Rationale for Action, may impact the transition experienced by the patients, which is why it should be thought through.

The results show that nursing practices in the hospital context are changing, shifting from the main focus on the biomedical component to care centered on the experiences of people faced with the imminence and inevitability of the end of life that may pave the way to a dignified and peaceful death.
In relation to the above, concerning the Rationale for Action, there are foci which were not recorded but are worth mentioning, perhaps because they reflect the attention that nurses are currently dedicating to the facilitation of transitions experienced by people, in the light of Afaf Meleis's references, for example, cognition, emotion, and willpower. It should be noted, however, that there is still a long way to go before the records consistently show such guidance.

To this end, it is crucial in academic and professional contexts to develop strategies that foster a more qualified professional approach to sick people and their families, during the experience of death and the processes of dying.

\section{References}

Brito, F. M., Costa, I. C., Costa, S. F., Andrade, C. G., Santos, K. F., \& Francisco, D. P. (2014). Comunicação na iminência da morte: Percepções e estratégia adotada para humanizar o cuidar em enfermagem. Escola Anna Nery: Revista de Enfermagem, 18(2), 317-322. doi:10.5935/1414-8145.20140046

Cardoso, F., Ribeiro, O., \& Martins, M. (2019). Death and dying: Contributions to a practice based on nursing theoretical frameworks. Revista Gaúcha de Enfermagem, 40. doi:doi.org/10.1590/19831447.2019.20180139

Despacho n. ${ }^{o} 1400-A / 2015$, de 10 de fevereiro. (2015). Diário da República n. ${ }^{\circ}$ 28/2015, $1^{\circ}$ Suplemento, Série II. Ministério da Saúde, Lisboa.

International Council of Nurses. (2001). CIPE/ICNP' - Classificação Internacional para a Prática de Enfermagem: Versão $\beta_{2}$. Lisboa, Portugal: Associação Portuguesa de Enfermeiros.

Lacerda, C. A., Camboim, F. E., Camboim, J. C., Nunes, E. M., Bezerra, A. L., \& Sousa, M. N. (2016). O lidar com a morte em unidades de terapia intensiva: Dificuldades relatadas por enfermeiros. Revista Ciência e Desenvolvimento, 9(2), 173-184. Retrieved from http://srv02.fainor.com.br/revista/index.php/ memorias/article/view/559/294

Lima, P. C., Comassetto, I., Faro, A. C., Magalhães, A. P., Monteiro, V. G., \& Silva, P. S. (2014). O ser enfermeiro de uma central de quimioterapia frente á morte do paciente oncológico. Escola Anna Nery: Revista de Enfermagem, 18(3) 503-509. Retrieved from: http://www.scielo.br/pdf/ean/v18n3/1414-8145-ean-18-03-0503.pdf 
Lindolpho, M. C., Caldas, C. P., Sá, S. P., \& Santos, N. D. (2016). Nursing care of the elderly in the end of life. Ciência, Cuidado e Saúde, 15(2), 383-389. doi: 10.4025/cienccuidsaude.v15i2.23904

Oliveira, S. G., Quintana, A. M., \& Bertolino, K. C. (2010). Reflexóes acerca da morte: Um desafio para a enfermagem. Revista Brasileira de Enfermagem 63(6) 1077-1080. doi:10.1590/S003471672010000600033

Salviano, M. E., Nascimento, P. D., Paula, M. A., Vieira, C. S., Frison, S. S., Maia, M. A., ... Borges, E. L. (2016). Epistemology of nursing care: A reflection on its foundations. Revista Brasileira de Enfermagem, 69(6),
1240-1245. doi:10.1590/0034-7167-2016-0331

Silva, A. A. (2001). Sistemas de Informação de enfermagem: Uma teoria explicativa da mudança (Tese de doutoramento). Instituto de Ciências Biomédicas Abel Salazar. Porto, Portugal.

Silva, A. A. (2006). Sistemas de informação em enfermagem: Uma teoria explicativa da mudança. Coimbra, Portugal: FORMASAU.

Sousa, D. M., Soares, E. O., Costa, K. M., Pacifico, A. L., \& Parente, A. C. (2009). A vivência da enfermeira no processo de morrer dos pacientes oncológicos. Texto Contexto Enfermagem, 18(1), 41-47. doi:doi. org/10.1590/S0104-07072009000100005 